Energy Resources Program

Prepared in cooperation with the Bureau of Land Management

\title{
An Assessment of the Economic Potential of Lignite and Leonardite Resources in the Williston Basin, North Dakota
}

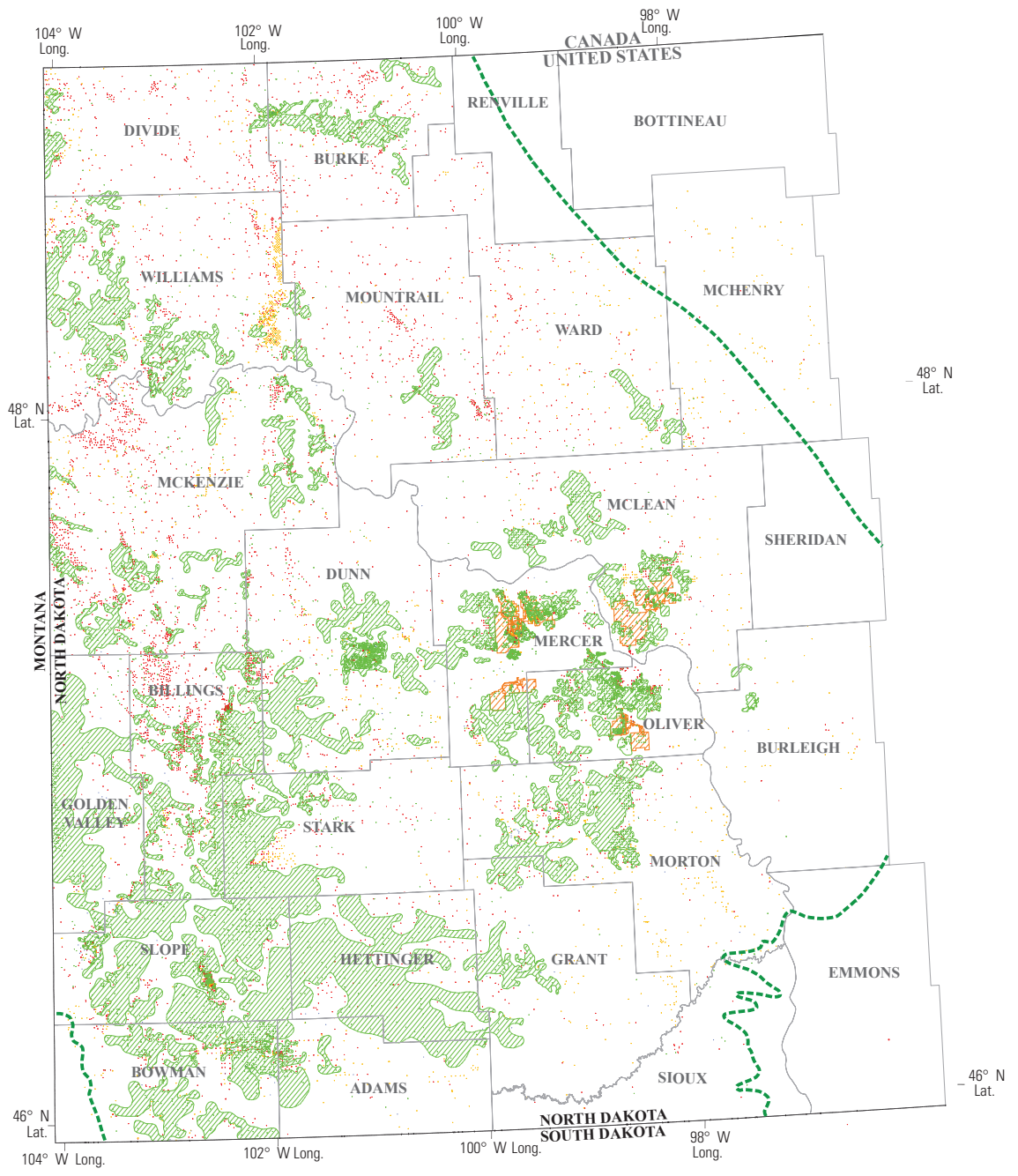

Open-File Report 2020-1135 
Cover. Map showing areas of potentially economic lignite resources in the study area in western North Dakota. 


\section{An Assessment of the Economic Potential of Lignite and Leonardite Resources in the Williston Basin, North Dakota}

By Brian N. Shaffer

Energy Resources Program

Prepared in cooperation with the Bureau of Land Management

Open-File Report 2020-1135 


\title{
U.S. Department of the Interior \\ DAVID BERNHARDT, Secretary
}

\author{
U.S. Geological Survey \\ James F. Reilly II, Director
}

U.S. Geological Survey, Reston, Virginia: 2021

For more information on the USGS - the Federal source for science about the Earth, its natural and living resources, natural hazards, and the environment—visit https://www.usgs.gov or call 1-888-ASK-USGS.

For an overview of USGS information products, including maps, imagery, and publications, visit https://store.usgs.gov/.

Any use of trade, firm, or product names is for descriptive purposes only and does not imply endorsement by the U.S. Government.

Although this information product, for the most part, is in the public domain, it also may contain copyrighted materials as noted in the text. Permission to reproduce copyrighted items must be secured from the copyright owner.

Suggested citation:

Shaffer, B.N., 2021, An assessment of the economic potential of lignite and leonardite resources in the Williston

Basin, North Dakota: U.S. Geological Survey Open-File Report 2020-1135, 14 p., https://doi.org/10.3133/ofr20201135.

ISSN 2331-1258 (online) 


\section{Acknowledgments}

The author acknowledges the Miles City, Montana, Field Office of the Bureau of Land Management, which provided external funding for this assessment study. The author also acknowledges the assistance of Peter D. Warwick of the U.S. Geological Survey in Reston, Virginia, for providing access to references, advice, and a peer review of the manuscript. Likewise, the author acknowledges the assistance of James A. Luppens, U.S. Geological Survey Emeritus Scientist, for his peer review of the manuscript and helpful suggestions, and the assistance of Edward C. Murphy of the North Dakota Geological Survey in providing information on the stratigraphic position and lateral relationships of lignite beds. 



\section{Contents}

Acknowledgments ……...................................................................................................................

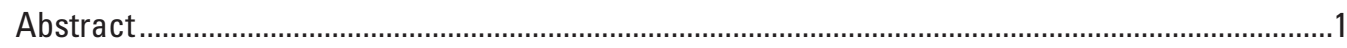

Introduction

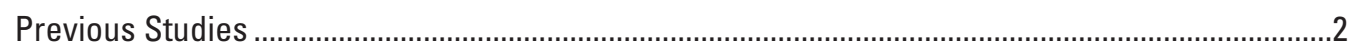

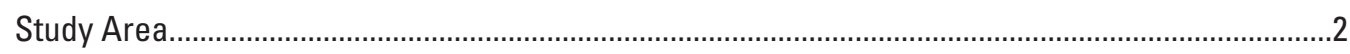

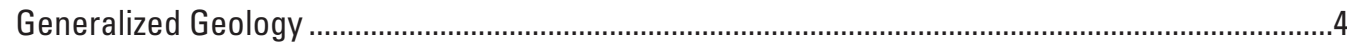

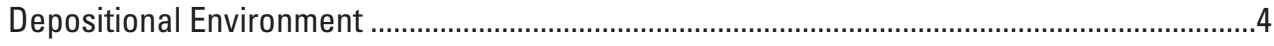

Regional Lignite Bed Stratigraphy …...................................................................................

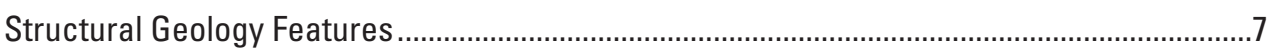

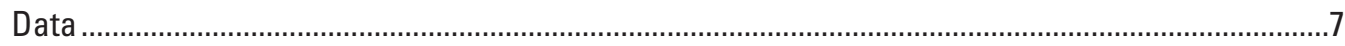

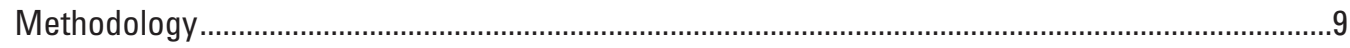

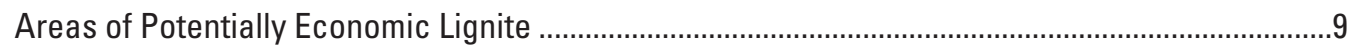

Areas of Potentially Economic Leonardite ..............................................................................11

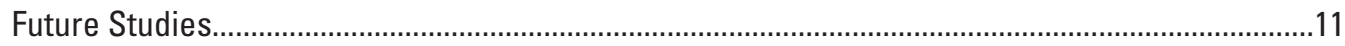

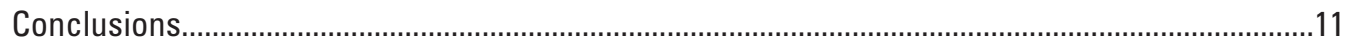

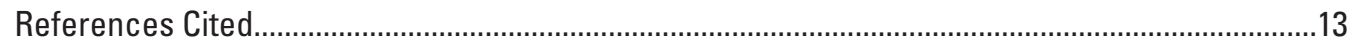

\section{Figures}

1. Map showing location of the study area in western North Dakota, showing

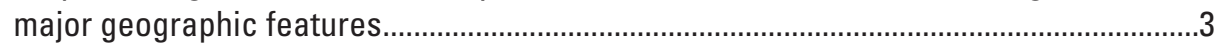

2. Diagram showing generalized geology and lignite bed stratigraphy for the study

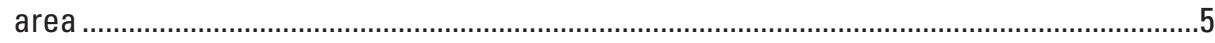

3. Map showing generalized structural geology features in the study area ........................6

4. Map showing location and distribution of nonproprietary data points in the

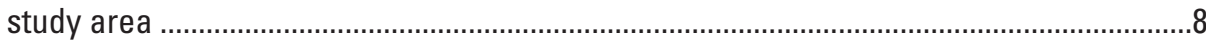

5. Map showing areas of potentially economic lignite resources in the study area ..........10

6. Map showing areas of potentially economic leonardite resources in the study area ...12 


\section{Conversion Factors}

U.S. customary units to International System of Units

\begin{tabular}{lcl}
\hline \multicolumn{1}{c}{ Multiply } & By & To obtain \\
\hline \multicolumn{3}{l}{ Length } \\
\hline foot $(\mathrm{ft})$ & 0.3048 & meter $(\mathrm{m})$ \\
\hline square mile $\left(\mathrm{mi}^{2}\right)$ & Area & \\
\hline & 2.590 & square kilometer $\left(\mathrm{km}^{2}\right)$ \\
\hline pound per cubic foot $\left(\mathrm{lb} / \mathrm{ft}^{3}\right)$ & Density & \\
\hline & 16.02 & kilogram per cubic meter $\left(\mathrm{kg} / \mathrm{m}^{3}\right)$ \\
\hline British thermal unit per pound $(\mathrm{Btu} / \mathrm{lb})$ & 2,326 & joule per kilogram $($ joule $/ \mathrm{kg})$ \\
\hline
\end{tabular}

\section{Abbreviations}

BLM Bureau of Land Management

NCRDS National Coal Resources Data System

NDGS North Dakota Geological Survey

USGS U.S. Geological Survey 


\title{
An Assessment of the Economic Potential of Lignite and Leonardite Resources in the Williston Basin, North Dakota
}

\author{
By Brian N. Shaffer
}

\section{Abstract}

The Bureau of Land Management (BLM) requested assistance from the U.S. Geological Survey (USGS) to conduct an assessment study to identify areas that may have economic potential for the future extraction of lignite and leonardite resources in the Williston Basin in North Dakota. The study will be used by the BLM to assist with the preparation of a revised resource management plan for the Williston Basin, in accordance with BLM planning policies.

The assessment of the economic potential of lignite resources required the establishment of criteria defining an economic lignite deposit. In consultation with the BLM, criteria were established to delineate drill holes that contained economic lignite beds. The criteria established are a minimum lignite bed thickness, a minimum cumulative lignite thickness, a maximum cumulative stripping ratio, and a maximum overburden. Likewise, an assessment of the economic potential of leonardite deposits required the establishment of criteria delineating drill holes that contained economic leonardite deposits. The criteria established are a minimum leonardite bed thickness, a minimum cumulative leonardite thickness, and a maximum overburden.

The drill hole data utilized in this study were obtained from the National Coal Resources Data System database and from several coal companies. Data from more than 20,000 drill holes, both proprietary and nonproprietary, were used to compile areas of economic potential for lignite or leonardite.

Areas delineated as having lignite or leonardite resources with economic potential, based on the established criteria, were present in 24 counties in the western portion of North Dakota. Areas of economic potential were delineated using a visual best-fit method without croplines. Areas defined as having economic potential for certain lignite beds or leonardite deposits may extend beyond known croplines in this study.

Stratigraphically, the lignite and leonardite deposits in the Williston Basin in North Dakota are mostly found in the Paleocene Fort Union Formation. Thick (greater than 20 feet) and laterally extensive (greater than 5 square miles) lignite beds are present in the Fort Union Formation throughout the Sentinel Butte and Tongue River Members. Lignite beds are also present in the Ludlow Member of the Fort Union Formation, although they are not as numerous or thick as they are in the overlying Sentinel Butte and Tongue River Members. As a result of lateral facies changes and migrating fluvial channel complexes in the Fort Union Formation, lignite beds of varying thickness occupy different stratigraphic horizons vertically throughout the Williston Basin.

The calculation of volumes for lignite and leonardite resources was not part of the scope of this study requested by the BLM, but a future study by the USGS may involve a comprehensive assessment of lignite resources and reserves in the Williston Basin. This future study could combine geologic data compiled in this study with geologic data from a previously unpublished 2019 assessment study by the USGS in the Williston Basin in eastern Montana. This future USGS study could also include the calculation of volumes for lignite resources and reserves, based on economic models derived using analogs from active mining operations in the Williston Basin and available spot market or contract coal prices.

\section{Introduction}

The Miles City, Montana, Field Office of the Bureau of Land Management (BLM) requested assistance from the U.S. Geological Survey (USGS) to conduct a study to identify areas in the Williston Basin of North Dakota that may have economic potential for the future extraction of minerals, including leonardite and lignite. The study will be used by the BLM to assist with the preparation of a revised resource management plan for the Williston Basin, in accordance with BLM planning policies. Assistance from the USGS for this assessment was requested because the USGS had the personnel, resources, and expertise to conduct a study within the time period allotted to prepare the revised resource management plan (less than 1 year). The study included identifying areas of economic potential for lignite and leonardite resources. The U.S. Coal Resources and Reserves Assessment Project of the USGS, which conducts regional-scale coal resource and reserve assessments of major coal beds in the United States, was requested to complete that task.

Lignite is a brownish-black, low-rank coal with a heat value of less than 8,300 British thermal units per pound when measured on a moist, mineral-matter-free basis (Wood and others, 1983). Leonardite is partially oxidized lignite 
found along outcrop areas where the overburden is thin and sufficiently porous to permit oxidation (Cvancara, 1955).

Leonardite has a variety of commercial uses, including as a wood stain, a soil conditioner, and an oil well drilling mud additive.

\section{Previous Studies}

Two recent studies have been published that evaluated lignite resources in the Williston Basin. A study by the North Dakota Geological Survey (NDGS) (Murphy, 2006) documented the quantity and extent of lignite resources and reserves on a county-by-county basis in North Dakota. The criteria used to evaluate and define economic lignite deposits in that study differ from the criteria that are used to define potentially economic lignite and leonardite deposits in this study. An earlier study by the USGS (Ellis and others, 1999) calculated lignite resources in the Williston Basin in North Dakota based on overburden thicknesses and net coal thickness of the lignite beds targeted in the study, but did not consider cumulative stripping ratios or apply any other economic factors. The study by Ellis and others (1999) also did not calculate the coal resource for lignite beds within the overburden of target lignite beds that could be extracted during the mining process.

\section{Study Area}

The assessment of the economic potential of lignite and leonardite in the Williston Basin encompasses all or parts of 24 counties in western North Dakota: Adams, Billings, Bowman, Burke, Burleigh, Divide, Dunn, Golden Valley, Grant, Hettinger, McHenry, McKenzie, McLean, Mercer, Morton, Mountrail, Oliver, Renville, Sheridan, Sioux, Slope, Stark, Ward, and Williams. Lignite deposits underlie an area of approximately 32,000 square miles (Murphy, 2006). The location of the assessment area in western North Dakota is shown in figure 1.

Larger towns within the study area include Bismarck, Bowman, Dickinson, Minot, Washburn, and Williston. The Missouri and Little Missouri Rivers transect the study area. Dams have been built across the Missouri River in two places within the study area, forming Lake Sakakawea and Lake Oahe. Two major highways cross through western North Dakota in an east-west direction: U.S. Route 2 in the northern half of the study area and Interstate Highway 94 in the southern half of the study area. Several U.S. highways cross through western North Dakota in a north-south direction. The rivers, lakes, and highways are shown in figure 1.

Four active mines produce lignite using surface mining methods within the study area in McLean, Mercer, and Oliver Counties. The Coyote Creek, Falkirk, and Freedom Mines are operated by North American Coal Company. The Center Mine is operated by BNI Coal. One additional permit has been issued to Westmoreland Coal Company for the Beulah Mine, but according to the BLM, development of the mine has been halted and the site is being reclaimed (C.D. Shilling, BLM, written commun., 2020). The permit areas for the active mines and the Beulah Mine are shown in figure 1. 


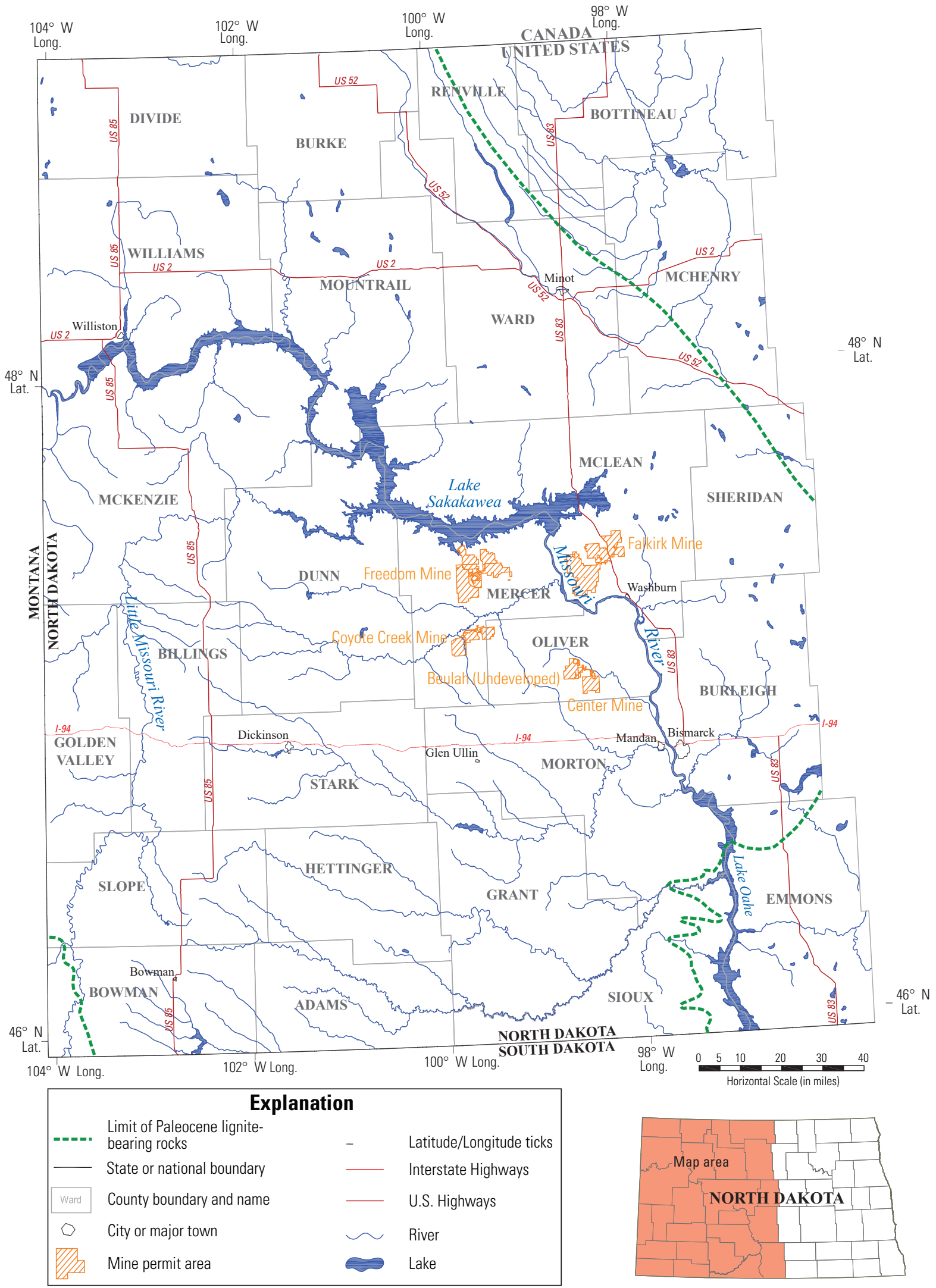

Figure 1. Map showing location of the study area in western North Dakota, showing major geographic features. 


\section{Generalized Geology}

Rocks cropping out at the surface in the Williston Basin within the study area range in age from Late Cretaceous to Pleistocene (Bluemle, 2003). Almost all of these rocks are sedimentary in origin and include sandstones, siltstones, mudstones, lignite beds, claystones, thin carbonate beds, and glacial deposits. Volcanic ash beds (tonsteins) are interbedded in these sedimentary rocks throughout western and central North Dakota (NDGS, 2020). Lignite occurs as beds of variable thickness mainly in the Paleocene Fort Union Formation. Lignite beds are more numerous and are generally thicker in the upper part of the Fort Union Formation (Flores and others, 1999). Several of these lignite beds exceed 20 feet in thickness within the study area. Leonardite, as previously noted, is present within the study area along the outcrop areas of lignite beds.

The assessment of potentially economic lignite and leonardite resources in this study is limited to beds that occur in the Paleocene Fort Union Formation. This study uses stratigraphic nomenclature recognized by the USGS (Flores and Keighin, 1999). Figure 2 shows the subdivision of Late Cretaceous, Paleocene, and Eocene rocks into their respective geological units within the study area.

\section{Depositional Environment}

The depositional environments of the Fort Union Formation within the study area vary from marine to fluvial deposits. According to Warwick and others (1996, 2004), the study area lies on the western edge of the Paleocene Cannonball Sea, which was a remnant of the Cretaceous Western Interior Seaway, and sediment deposition was influenced by an overall westward transgression followed by a series of eastward regressive sequences. The stratigraphically lowest unit in the Fort Union Formation, the Ludlow Member, is composed of lower delta plain and coastal plain sediments. The unit interfingers with the marine sediments of the Cannonball Member, which is present in the eastern portion of the study area but pinches out towards the west. Maximum westward transgression of the Cannonball Sea occurred during deposition of the Ludlow/Cannonball Members, after which eastward regression commenced. The overlying Tongue River Member of the Fort Union Formation is composed of sediments deposited in a lower delta plain fluvial environment as the Cannonball Sea receded. As the eastward regression of the Cannonball Sea continued into the late Paleocene, the Sentinel Butte Member sediments were deposited in a fluvialdominated environment featuring peat swamps separated by wide fluvial paleochannels, levees, and floodplains.

\section{Regional Lignite Bed Stratigraphy}

Lignite beds are present throughout the Fort Union Formation (fig. 2). Most of these lignite beds are laterally discontinuous, with a thick central core deposit that thins and splits into two or more benches as they approach laterally adjacent fluvial channel deposits. The Ludlow Member contains numerous thin, laterally discontinuous lignite beds that are unnamed. The T-Cross lignite bed is the thickest of the Ludlow Member lignite beds. The bed lies approximately 300-350 feet below the top of the Ludlow Member, but can be difficult to identify where multiple lignite beds are present in the Ludlow Member (Carlson, 1983).

The occurrence of lignite beds increases in the Tongue River Member. The H lignite bed occurs sporadically slightly above the basal contact of the member. The most laterally continuous lignite beds in the Fort Union Formation in the study area are the Harmon and Hanson beds. [The name Hanson is used in this study, as described by the NDGS (Murphy, 2002), rather than the previous usage of Hansen, such as in Flores and others (1999).] The Hanson lignite bed lies approximately 60-100 feet above the $\mathrm{H}$ lignite bed. The Harmon lignite bed lies between 40-100 feet above the Hanson lignite bed and is the thickest lignite bed observed in the study area. As interpreted from available drill hole data, the Harmon lignite bed attains a thickness of more than 50 feet in southern McKenzie County, but at depths of cover of more than 400 feet. Several other locally thick lignite beds are present in the Tongue River Member, including Alkabo (Divide County), the Garner Creek (Billings, Dunn, Golden Valley, and Stark Counties), and Tavis Creek (McLean, Mercer, and Oliver Counties) beds (fig. 2).

The greatest number of lignite beds in the Fort Union Formation are in the Sentinel Butte Member. Different lignite beds are present at different stratigraphic positions across the axis of the Williston Basin (fig. 3). This is reflective of the depositional environment, where the lateral continuity of lignite deposits is interrupted by bordering fluvial channel systems. On the western side of the axis of the basin, the HT Butte lignite bed is present at the base of the member. The base of the HT Butte lignite is the basal contact of the Sentinel Butte Member (Carlson, 1983). Lying approximately 60 feet above the HT Butte lignite bed is the Fryburg lignite. Approximately 70 feet above the Fryburg lignite lies the Heart River lignite bed. Approximately 200 feet above the HT Butte lignite is a lignite bed identified as the Lehigh lignite (Carlson, 1983).

On the eastern side of the axis of the basin, the HT Butte lignite is absent, so the basal contact of the Sentinel Butte Member must be approximated based on its interval from the Harmon lignite bed. The lowermost lignite in the Sentinel Member on the eastern side of the axis is the Hagel bed, which 


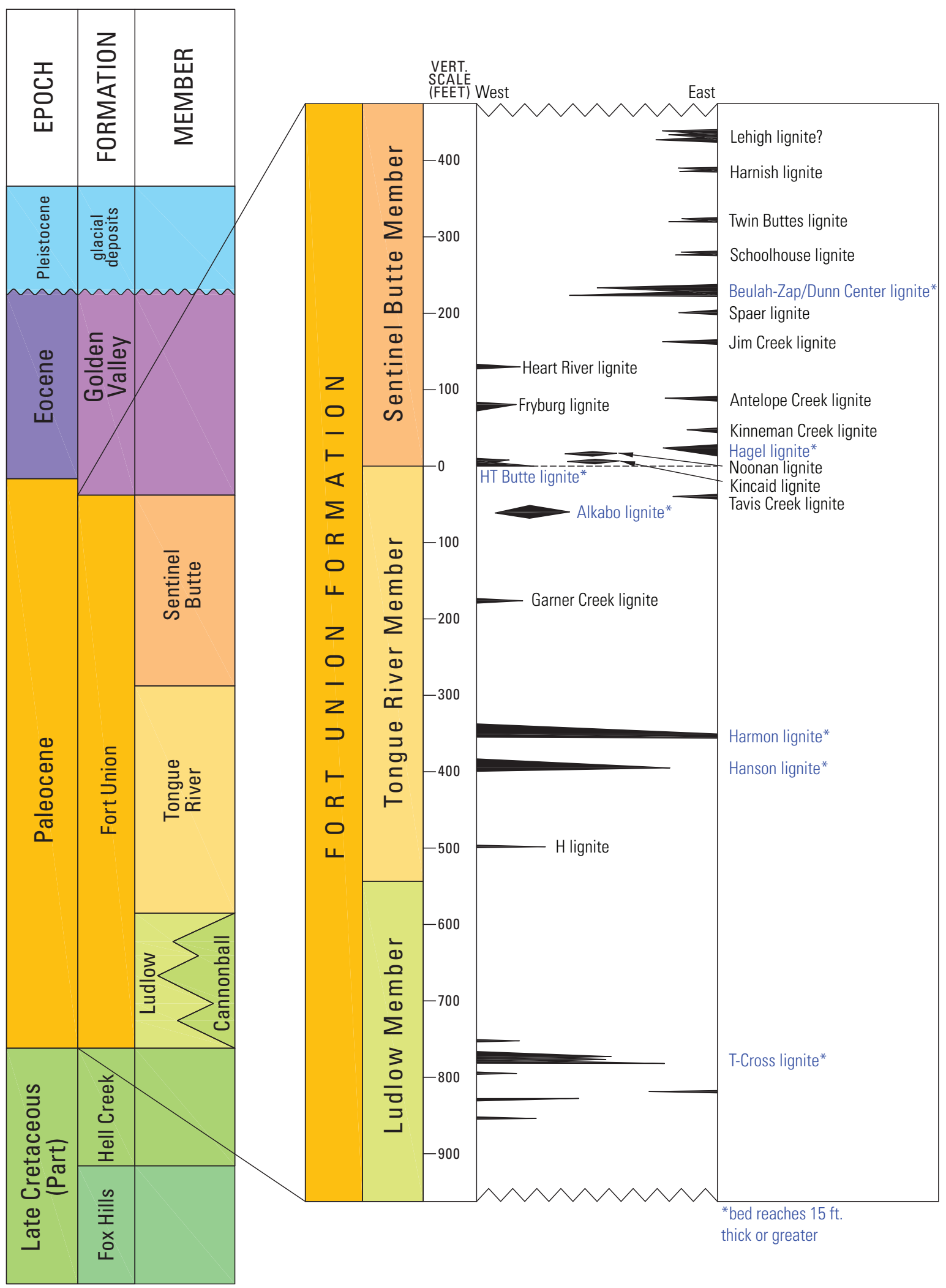

Figure 2. Diagram showing generalized geology and lignite bed stratigraphy for the study area. (ft., feet; VERT., vertical) 


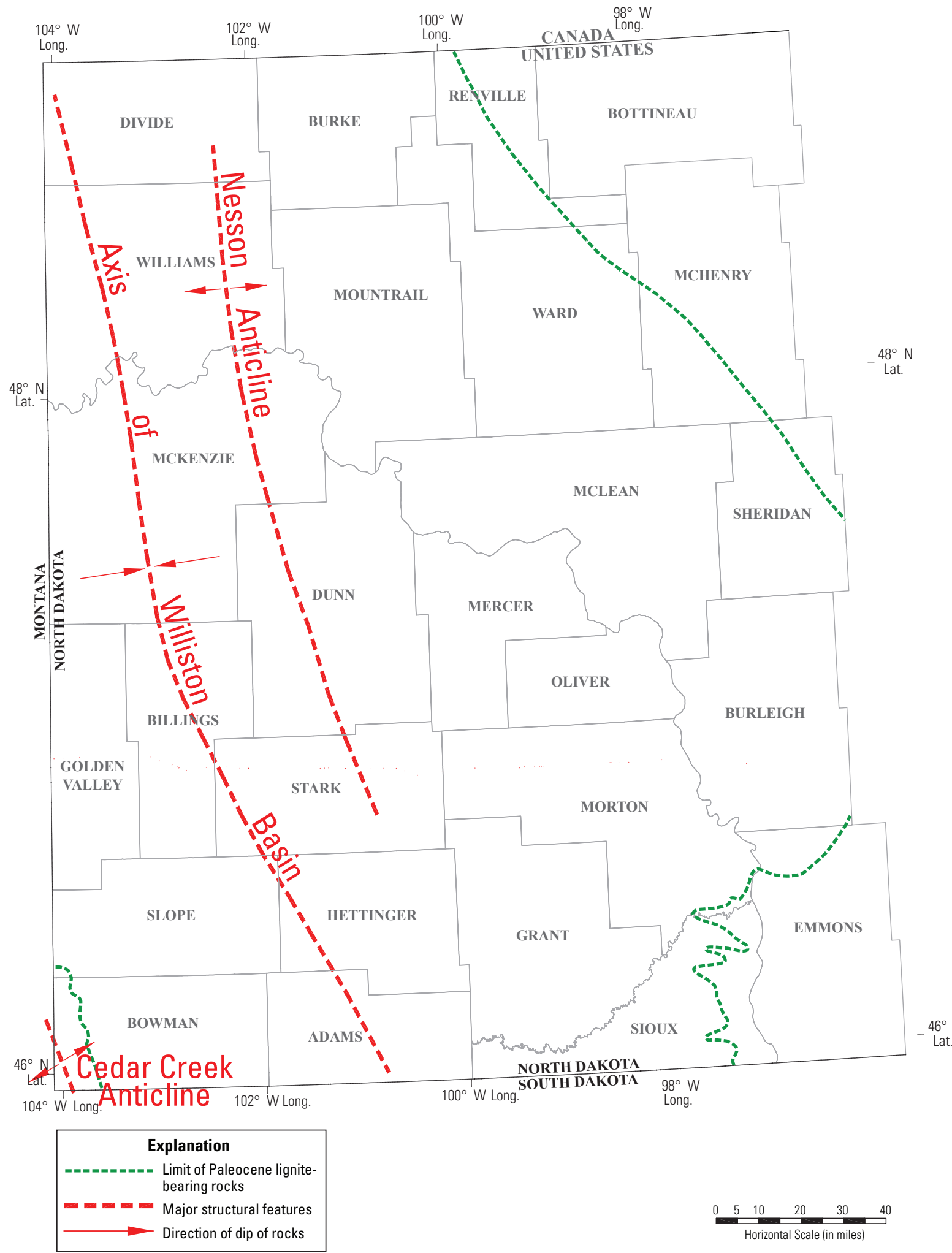

Figure 3. Map showing generalized structural geology features in the study area. (Adapted from Flores and Keighin, 1999.) 
appears to lie approximately $30-50$ feet above the projected base of the member. Ascending upward stratigraphically are several locally thick, but laterally discontinuous lignite beds, including the Kinneman Creek, Antelope Creek, Jim Creek, and Spaer. Lying approximately 190 feet above the Hagel lignite bed is the Beulah-Zap lignite bed and its western lateral equivalent, the Dunn Center lignite bed. Both the Beulah-Zap and Dunn Center lignite beds exceed 20 feet in thickness. The four active lignite surface mining permits in the study area target lignite beds in the Sentinel Butte Member. Several thin, discontinuous lignite beds overlie the Beulah-Zap lignite bed, including the Schoolhouse, Twin Buttes, and Harnish beds (Groenewold and others, 1979).

The stratigraphic location of the Noonan and Kincaid lignite beds appears to be ambiguous. Hansen (1967) states that lignite was produced from the Noonan bed in the Tongue River Member in Divide County, and Freers (1973) states that the lignite mined from the same beds in Burke County are in the Sentinel Butte Member. The Noonan and Kincaid lignite beds in this study are placed in the very lowest portion of the Sentinel Butte Member stratigraphically, which is consistent with the current NDGS usage (Murphy, 2006).

Differing stratigraphic intervals for lignite beds in the Sentinel Butte Member are interpreted by Hinds (1983) for the southern part of the study area in Slope and Stark Counties. The Fryburg lignite is interpreted to be 110-220 feet above the HT Butte bed, with the Heart River lignite overlying the Fryburg by an interval ranging from 20-110 feet. Additional research needs to be conducted on a regional scale to confirm the stratigraphic positions and intervals of all the beds described above. The relative stratigraphic positions and approximate stratigraphic intervals of the lignite beds described above are shown in figure 2.

\section{Structural Geology Features}

The dominant structural geologic feature within the study area is the synclinal trough known as the Williston Basin, whose axis passes through the study area in a north-northwest to south-southeast strike (fig. 3). The Nesson anticline is just to the east of the axis of the basin in the central portion of the study area, running parallel to the basin axis through eastern Williams, eastern McKenzie, Dunn, and Stark Counties. The Cedar Creek anticline crosses through Bowman County in the very southwestern corner of the study area, paralleling the axis of the Williston Basin. Upper Cretaceous strata are exposed along the axis of this anticline.

Small-scale and localized undulations in the regional structural trends can be observed when posting structural elevations for lignite beds throughout the study area. Abrupt changes in structural trends with variations of greater than 50 feet from the projected trend are not uncommon. It cannot be determined from the data available whether these abrupt local structural changes are monoclinal features, localized anticlines or synclines, or small-scale faults induced by differential compaction of laterally adjacent sediments. The major structural geology features within the study area are shown in figure 3, as adapted from USGS Professional Paper 1625-A, Chapter WS (Flores and Keighin, 1999).

\section{Data}

The geological database utilized in this study was compiled from data obtained from the National Coal Resources Data System (NCRDS) database of the USGS and from individual coal companies within the study area. The NCRDS is available at https://www.usgs.gov/centers/eersc/science/ national-coal-resources-data-system-ncrds?qt-science_center_ objects $=0 \# q t-s c i e n c e$ center_objects. The individual data points that compose the geologic database consist of drill hole records and measured sections from within the study area. The database is composed of 23,397 data points, of which 20,271 data points were obtained from the NCRDS database. In the NCRDS data, 1,928 data points out of the 20,271 were designated as proprietary. Data for a total of 3,126 drill holes were obtained from individual coal companies. All coal company data were treated as proprietary, as per agreements with the BLM. The proprietary data were used in determining the areas of economic potential for lignite and leonardite resources, but the locations of those proprietary data points are not posted in any of the figures used in this study. The locations of the 18,343 nonproprietary data points used in this study are shown in figure 4 . The geological database compiled for this study used more than 4,000 additional drill holes compared to the most recent assessment of lignite reserves in North Dakota by the NDGS (Murphy, 2006). 

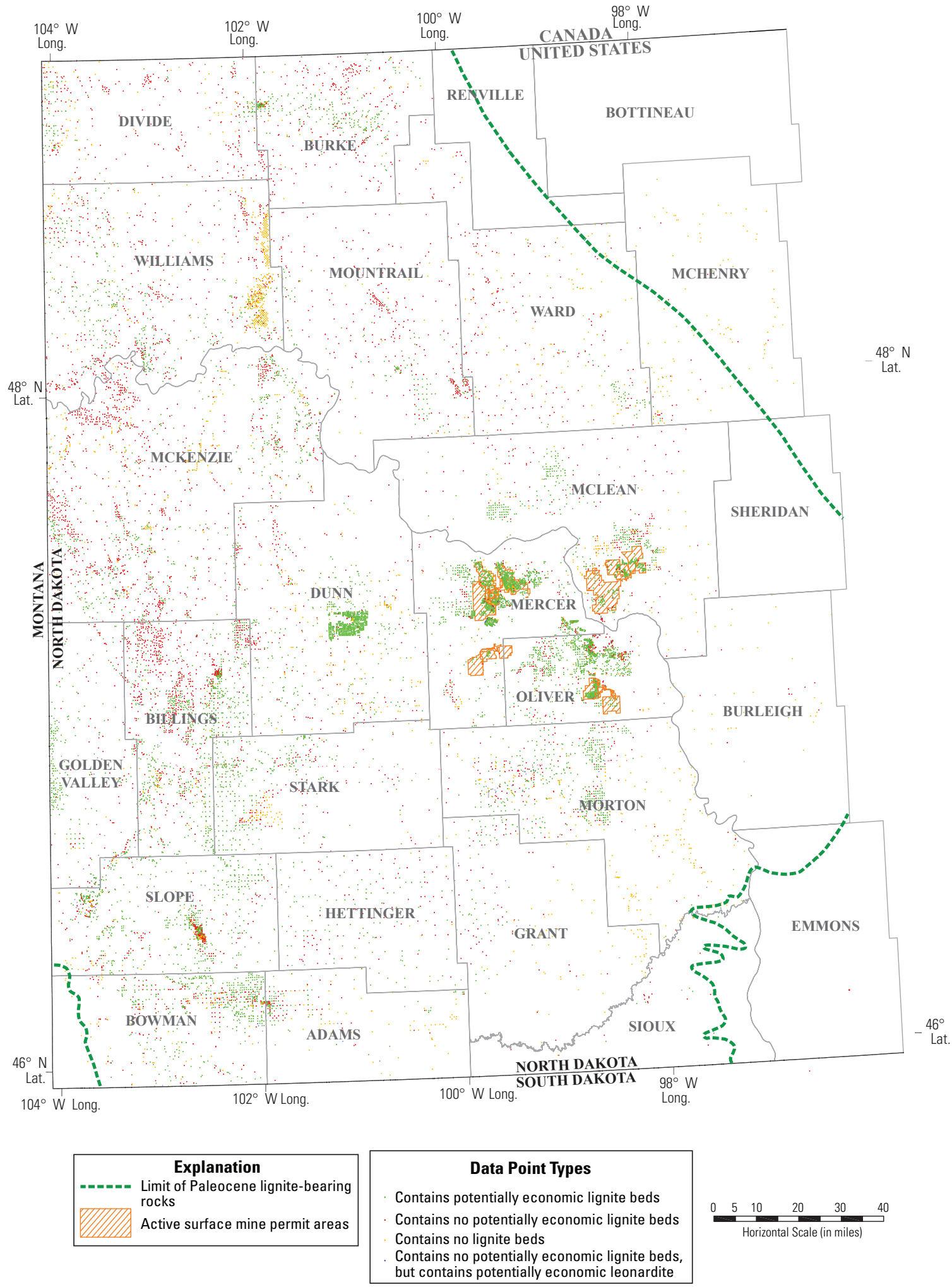

Figure 4. Map showing location and distribution of nonproprietary data points in the study area. 


\section{Methodology}

After the geologic database was compiled, the data points were sorted into four categories based on criteria agreed upon by the BLM and the USGS. The four data point categories are as follows:

1. Potentially economic. The data point contains a lignite bed or beds that meet the criteria for a potentially economic lignite deposit.

2. Noneconomic. The data point contains a lignite bed or beds, but none meet the criteria for a potentially economic lignite deposit.

3. No coal. The data point contains no lignite beds.

4. Leonardite. The data point contains a lignite bed or beds that do not meet the criteria for a potentially economic lignite deposit but meet the criteria for a potentially economic leonardite deposit.

The criteria used to determine whether a data point contains potentially economic lignite beds are

1. at least one lignite bed 2 feet thick or greater;

2. a cumulative lignite thickness of 2 feet or greater;

3. a cumulative stripping ratio of 15:1 or less;

4. a maximum depth of cover of less than 300 feet to the top of the deepest lignite bed meeting the thickness and cumulative stripping ratio criteria; and

5. a minimum depth of cover of 25 feet to the top of the bed.

Stripping ratios were calculated using a formula of bank cubic yards of overburden divided by tons of coal under the overburden area, with a coal density of 80 pounds per cubic foot. (A "bank cubic yard" is a measure of the overburden in its original in situ position, which has not been blasted or otherwise disturbed [U.S. Bureau of Mines, 1996.] No bulking factor is applied to the overburden.)

The criteria used to determine whether a data point contains potentially economic leonardite are

1. at least one leonardite bed of 2 feet or greater;

2. a cumulative leonardite thickness of 2 feet or greater; and

3. a depth of cover of 25 feet or less or where greater than 50 percent of the bed was at 25 feet of cover or less for the deepest bed meeting the thickness criteria.

Areas of potential economic resources for both lignite and leonardite were delineated in the geologic database using a visual best-fit method that placed the boundary between a data point with potentially economic beds and a data point with no potentially economic beds approximately halfway between the data points. This visual best-fit method was chosen for this study due to the time limitations placed for the completion of this study by the BLM. An area considered for potentially economic lignite beds had to contain at least five data points designated as potentially economic within close proximity to one another. Outcrops for the potentially economic beds were not determined and, therefore, not used to assist in the delineation of areas of potentially economic beds. Areas defined as containing potentially economic beds may extend beyond projected or known croplines in this study. Also, areas of previous mining were not considered when determining areas of potentially economic lignite and leonardite beds. Some of the areas projected as having potentially economic beds may overlap onto areas of previous mining. The BLM may alter projected potentially economic areas where they overlap previously mined areas in their revised resource management plan.

The criteria used in this study differ from those used in the study of lignite reserves by the NDGS (Murphy, 2006). The criteria used in the NDGS study were more conservative than the criteria used in this study. The NDGS criteria were

1. a minimum cumulative thickness of 10 feet;

2. a minimum individual bed thickness of 2.5 feet;

3. a maximum stripping ratio of $10: 1$;

4. a maximum depth of cover of 150 feet; and

5. a minimum depth of cover of 20 feet.

The criteria adopted for this study were developed by the USGS and the BLM with input from regional coal companies. The goal of using these broader criteria rather than the more restrictive NDGS criteria was to include as much of the potentially economic lignite and leonardite resources as possible in the BLM's revised resources management plan for the Williston Basin.

\section{Areas of Potentially Economic Lignite}

Areas of potentially economic lignite resources, based on the stated criteria, occur throughout the study area, as shown in figure 5. In the portion of the study area west of the axis of the Williston Basin, most of the potentially economic lignite resources are located stratigraphically in the Tongue River Member of the Fort Union Formation. In the portion of the study area east of the axis of the basin, most of the potentially economic lignite resources are located stratigraphically in the Sentinel Butte Member of the Fort Union Formation. This includes potentially economic lignite resources adjacent to the active mining permit areas. 


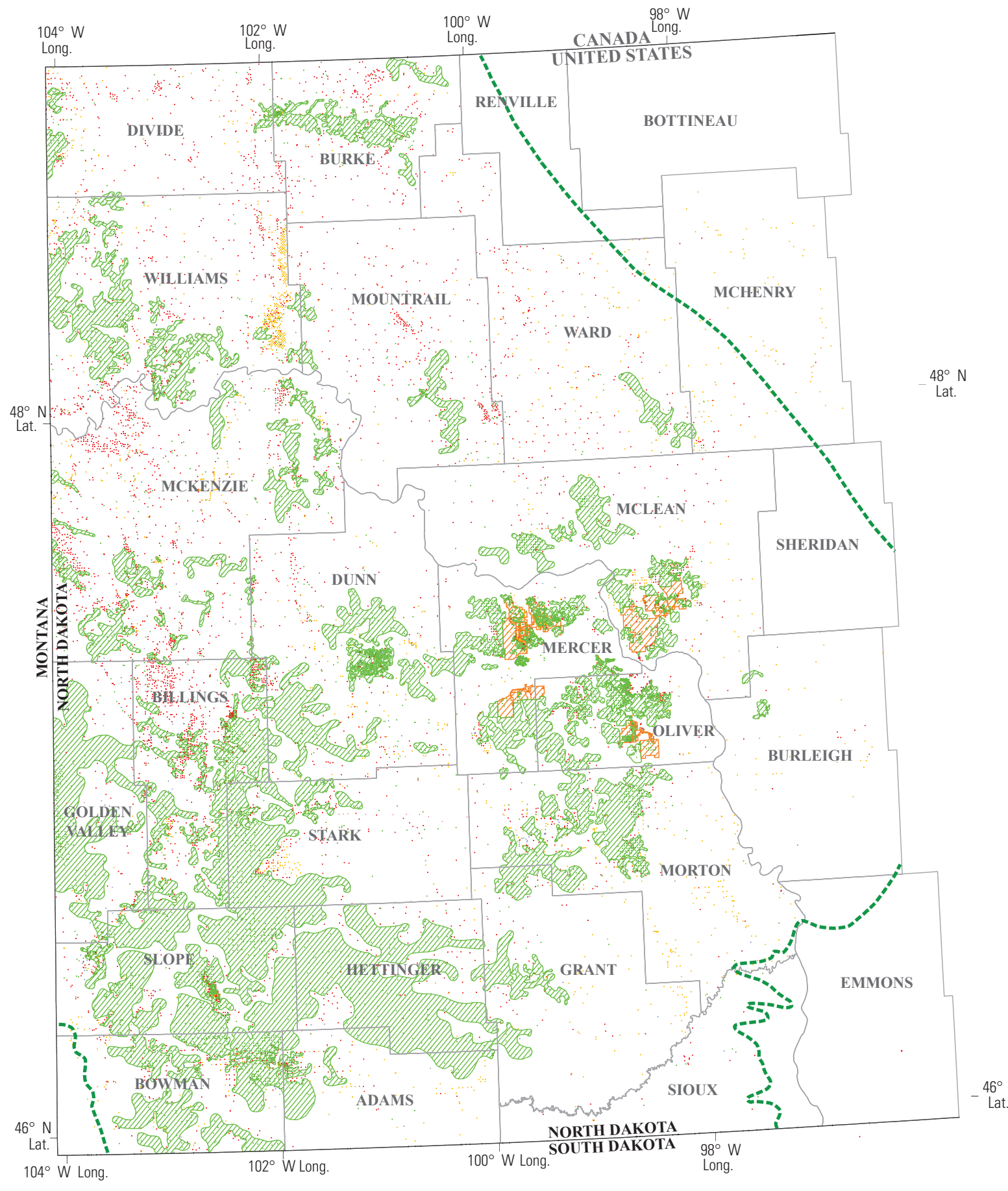

\begin{tabular}{|l|}
\hline \multicolumn{1}{c|}{ Explanation } \\
Limit of Paleocene lignite bearing- \\
rocks \\
Active surface mine permit areas \\
Areas of potentially economic \\
lignite resources
\end{tabular}

\begin{tabular}{|l|}
\hline \multicolumn{1}{|c|}{ Data Point Types } \\
Contains potentially economic lignite beds \\
Contains no potentially economic lignite beds \\
Contains no lignite beds \\
Contains no potentially economic lignite beds \\
but contains potentially economic leonardite
\end{tabular}

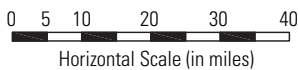

Figure 5. Map showing areas of potentially economic lignite resources in the study area. 


\section{Areas of Potentially Economic Leonardite}

Areas of potentially economic leonardite resources, based on the stated criteria, are scattered and sporadic throughout the study area, as shown in figure 6. All the areas identified as potentially economic for leonardite are located along croplines and may have been subject to burning, weathering, or oxidation, turning the potential leonardite to clinker.

\section{Future Studies}

Although the scope of this study as requested by the BLM did not involve the calculation of volumes for lignite and leonardite resources, the study provides the USGS with a complete and refined geologic database for the area. A thorough assessment of the lignite resources for the Williston Basin in both Montana and North Dakota has been proposed for future study by the U.S. Coal Resources and Reserves Assessment Task of the Evolving Utilization of Solid Energy Fuels Project of the USGS. Such work could combine the results of this study and those of an unpublished 2019 study of the Williston Basin of eastern Montana to provide a complete database for assessing lignite and leonardite resources for the entire Williston Basin, as well as providing the potential to refine stratigraphic relationships between lignite beds across the basin and between the States. The proposed study could include the calculation of volumes for lignite resources and incorporate economic modeling to determine reserves. This study could further delineate lignite and leonardite resource areas with economic potential, based on the current criteria for defining potentially economic lignite beds and using distancebased resource classifications as described in Wood and others (1983). Areas of potential economic lignite reserves may also be calculated, based on economic models derived using analogs from active mining operations in the Williston Basin and available spot market or contract coal prices.

\section{Conclusions}

Using the available data and the criteria specified by the Bureau of Land Management, the purpose of this study was to define areas of potentially economic lignite and leonardite resources within the Williston Basin of North Dakota as a contribution to their revised resources management plan for the basin. The spatial extents of these areas have been provided to the Bureau of Land Management. Although extensive areas of potentially economic lignite resources were identified, as well as scattered and sporadic areas of potentially economic leonardite resources, the study did not undertake a complete and comprehensive assessment of lignite resources. 

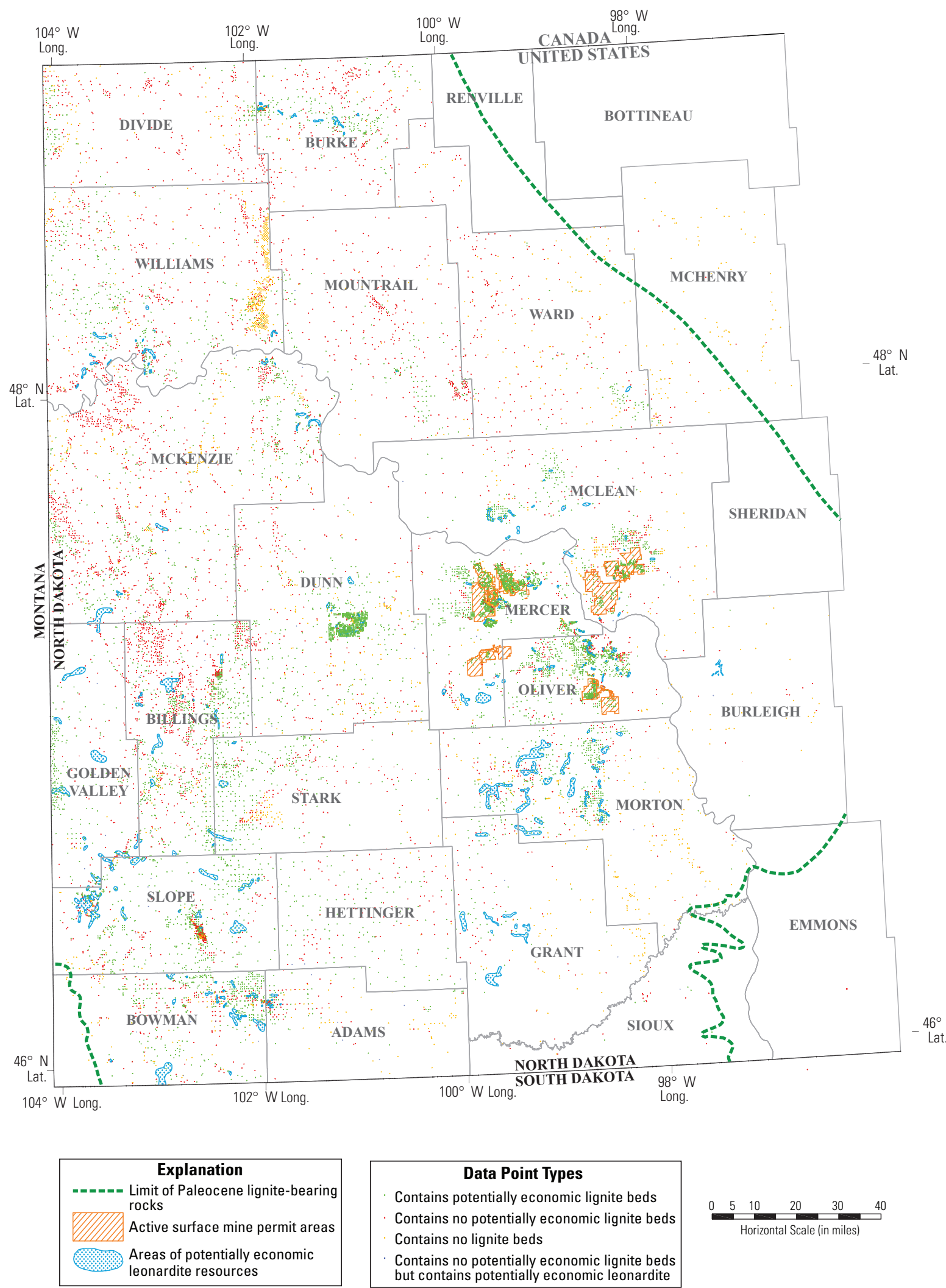

\section{Data Point Types}

Contains potentially economic lignite beds

Contains no potentially economic lignite beds Contains no lignite beds

Contains no potentially economic lignite beds but contains potentially economic leonardite

Figure 6. Map showing areas of potentially economic leonardite resources in the study area. 


\section{References Cited}

Bluemle, J.P., 2003, Generalized bedrock geologic map of North Dakota: North Dakota Geological Survey Miscellaneous Map 36, 1 sheet, accessed June 16, 2020, at https://www.dmr.nd.gov/ndgs/documents/Publication_List/ pdf/MisMaps/MM-36.pdf.

Carlson, C.G., 1983, Geology of Billings, Golden Valley, and Slope Counties, North Dakota: North Dakota Geological Survey Bulletin 76-Part 1 and North Dakota State Water Commission County Groundwater Studies 29-Part 1, 40 p., accessed April 9, 2020, at https://www.dmr.nd.gov/ ndgs/documents/outofprint/Bulletins/Bulletin\%2076.pdf.

Cvancara, A.M., 1955, Lignite-Valuable resource of North Dakota in Laird, W.M., ed., Contributions to the geology of North Dakota by students and staff, Department of Geology, University of North Dakota: North Dakota Geological Survey Bulletin 28, p. 133-137, accessed January 24, 2020, at https://www.dmr.nd.gov/ndgs/documents/outofprint/ bulletins/bulletin_28.pdf.

Ellis, M.S., Gunther, G.L., Ochs, A.M., Keighin, C.W., Goven, G.E., Schuenemeyer, J.H., Power, H.C., Stricker, G.D., and Blake, D., 1999, Coal resources, Williston Basin, chap. WN of 1999 resource assessment of selected Tertiary coal beds and zones in the Northern Rocky Mountains and Great Plains region: U.S. Geological Survey Professional Paper 1625-A, 74 p., accessed April 7, 2020, at https://pubs.usgs.gov/pp/p1625a/Chapters/WN.pdf.

Flores, R.M., and Keighin, C.W., 1999, Fort Union coal in the Williston Basin, North Dakota-A synthesis, chap. WS of 1999 resource assessment of selected Tertiary coal beds and zones in the Northern Rocky Mountains and Great Plains region: U.S. Geological Survey Professional Paper 1625-A, 45 p., accessed March 10, 2020, at https://pubs.usgs.gov/pp/ p1625a/Chapters/WS.pdf.

Flores, R.M., Keighin, C.W., Ochs, A.M., Warwick, P.D., Bader, L.R., and Murphy, E.C., 1999, Framework geology of Fort Union coal in the Williston Basin, chap. WF of 1999 resource assessment of selected Tertiary coal beds and zones in the Northern Rocky Mountains and Great Plains region: U.S. Geological Survey Professional Paper 1625-A, 70 p., accessed April 7, 2020, at https://pubs.usgs.gov/pp/ p1625a/Chapters/WF.pdf.

Freers, T.F., 1973, Geology of Burke County, North Dakota: North Dakota Geological Survey Bulletin 55-Part 1 and North Dakota State Water Commission County Groundwater Studies 14—Part 1, 32 p., 3 pls., accessed June 29, 2020, at https://www.dmr.nd.gov/ndgs/documents/ outofprint/Bulletins/Bulletin\%2055.pdf.
Groenewold, G.H., Cherry, J.A., Meyer, G.N., Hemish, L.A., Rehm, B.W., and Winczewski, L.M., 1979, Geology and geohydrology of the Knife River Basin and adjacent areas of west-central North Dakota: North Dakota Geological Survey Report of Investigation no. 64, 402 p., 37 pls., accessed April 29, 2020, at https://www.dmr.nd.gov/ndgs/ documents/Publication_List/pdf/RISeries/RI-64.pdf.

Hansen, D.E., 1967, Geology and ground water resources, Divide County, North Dakota: North Dakota Geological Survey Bulletin 45-Part 1, 90 p., 5 pls., accessed June 29, 2020, at https://www.dmr.nd.gov/ndgs/documents/ outofprint/Bulletins/Bulletin\%2045.pdf.

Hinds, J.S., 1983, Structural-stratigraphic framework and correlation of coal beds in the Tongue River and Sentinel Butte Members of the Fort Union Formation, Daglum 15-minute quadrangle, Billings, Stark, and Slope Counties, North Dakota: U.S. Geological Survey Miscellaneous Field Studies Map MF-1345-A, sheet 1 of 3, scale 1:62,500, accessed January 24, 2020, at https://pubs.usgs.gov/mf/ 1345-A/plate-1.pdf.

Murphy, E.C., 2002, The Hanson not Hansen lignite bed: Newsletter, N.D.G.S., North Dakota Geological Survey, vol. 29, no. 2, p. 1-2, accessed June 26, 2020 , at https://www.dmr.nd.gov/ndgs/documents/newsletter/ 2002Winter/PDF/hanson.pdf.

Murphy, E.C., 2006, The lignite reserves of North Dakota: North Dakota Geological Survey Report of Investigation no. 104, 141 p., accessed January 24, 2020, at https://www.dmr.nd.gov/ndgs/documents/Publication_List/ pdf/RISeries/RI-104.pdf.

North Dakota Geological Survey [NDGS], 2020, Mineral resources of North Dakota - Volcanic ash: North Dakota Geological Survey website, accessed April 9, 2020, at https://www.dmr.nd.gov/ndgs/mineral/volcanicAsh.asp.

U.S. Bureau of Mines, 1996, Dictionary of mining, mineral, and related terms ( $2 \mathrm{~d}$ ed.): U.S. Department of the Interior website, accessed June, 17, 2020, at http://xmlwords.infomine.com/xmlwords.htm.

Warwick, P.D., Flores, R.M., Nichols, D.J., and Murphy, E.C., 1996, Depositional sequences and correlations within the Fort Union Formation, Williston Basin, North Dakota and Montana [abs.], in American Association of Petroleum Geologists Convention and Exhibition, San Diego, Calif., May 19-22, 1996, Abstracts: AAPG Search and Discovery Article no. 91019, 1 p., accessed April 8, 2020, at http://www.searchanddiscovery.com/abstracts/html/1996/ annual/abstracts $/ 0147 \mathrm{c} \cdot \mathrm{htm}$. 
Warwick, P.D., Flores, R.M., Nichols, D.J., and Murphy, E.C., 2004, Chronostratigraphic and depositional sequences of the Fort Union Formation (Paleocene), Williston Basin, North Dakota, South Dakota, and Montana, in Gastaldo, R.A., and Pashin, J.C., eds., Sequence stratigraphy, paleoclimate, and tectonics of coal-bearing strata: American Association of Petroleum Geologists Studies in Geology 51, p. 121-145.

Wood, G.H., Jr., Kehn, T.M., Carter, M.D., and Culbertson, W.C., 1983, Coal resource classification system of the U.S. Geological Survey: U.S. Geological Survey Circular 891, 65 p. [Also available at https://doi.org/10.3133/cir891.] 
For more information concerning the research in this report, contact the

Center Director

USGS Central Energy Resources Science Center Box 25046, Mail Stop 939

Denver, CO 80225

(303) 236-1647

Or visit the Central Energy Resources Science Center website at

https://www.usgs.gov/energy-and-minerals/ energy-resources-program/

Publishing support provided by the

Science Publishing Network,

Denver Publishing Service Center 


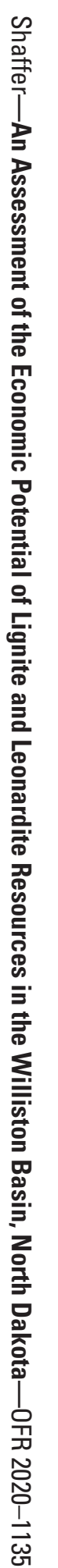

